\title{
11
}

\section{Funeral Reforms in Taiwan: Insights on Change from a Discourse Analytic Perspective}

\author{
Urs Weber
}

\section{Introduction}

This chapter focuses on the way Taiwan's written media justified the state's introduction of funeral reforms in the second half of the twentieth century. Situating this case study within the broader sociopolitical context of contemporary Taiwan, it illustrates how discourse analysis can be used as a tool for studying change.

Discourse analysis, as it is presented and applied in this chapter, aims at examining the discursive dimension of the process of reforming and changing funeral practice. It reveals how state authorities promoted new ideals and values concerning funeral practice, and argued for the need of reforms in a field of practice in which traditional rituals played an important role. Since the 1980 s, a series of corresponding reform measures, laws, and regulations were implemented on the national and local level.

\section{U. Weber $(\varangle)$}

Department of Religious Studies, University of Zurich, Zürich, Switzerland e-mail: urs.weber@rws.uzh.ch 
Change thus appears in this case as a consequence of political decisionmaking processes and reforms. The discourse analysis allows for grasping the public reasoning about reform measures regarded as necessary in the eyes of the authorities, journalists, and experts appearing as voices of the discourse. Since the discourse took place in mass media, the newspaper articles as textual data allow for an analysis of the discourse since its emergence in the 1970s.

The state's intervention in funerary practice marked a discontinuity in Taiwan. It came as an expression of the state's increasingly critical attitude toward religious funeral practices. In 1983, it enacted a new law, the Grave Establishment Administration Act (Fenmu shezhi guanli tiaoli 填墓設置管理條例), and in subsequent years, local authorities implemented measures to deal with Taiwan's land shortage and lack of space for graves due to its high population density. ${ }^{1}$ State and local authorities saw the prevalent practice of in-ground burial as land-consuming and expensive, and spoiling Taiwan's scenery, and saw geomancy, an important practice for choosing the grave spot, as superstitious.

The state's attitude to religious funerary practice was articulated via a public discourse in the written media. During the second half of the 1970s, the funeral reforms became a frequent topic of newspaper reports and articles. Journalists supporting the state's position reported and commented on the funeral reforms, and state institutions and authorities' statements containing criticism of ritual funerary practices were cited which served as both the justification and the reasoning behind the planned and the implemented reforms.

Already during the Chinese Republican period (1912-1949), the Nationalist Party (Guomindang 國民黨, GMD) had taken a secular attitude to reform funerary practice. After the Nationalists' retreat to Taiwan in 1949, however, the state's attitude to religious funeral rituals took on a different dimension. The island's geography and population development constituted a new context in which funeral and burial rituals became a focus of state criticism and regulation, leading to the implementation of concrete reforms.

\footnotetext{
${ }^{1}$ Hanyu Pinyin is used to romanize Chinese words and expressions except for place names for which alternative spellings are commonly used, e.g., Taipei, Changhua.
} 
How do we grasp the extent and scope of this change? How far did the arguments and rationales used by the promoters of these stateled changes indicate a break from previous norms and practices? How were the reforms perceived and articulated by social actors? This chapter argues that a discursive analytic perspective is a useful method for tackling these issues, and that applying this perspective on the rationales and arguments in favor of such reform and regulation allows a better grasp of the extent to which the state's position and its public articulation disrupted the tradition of conducting elaborate mourning and burial rituals.

Analysis of the public discourse on funerary practice reveals both the rupture and the continuity of the articulated funerary practice norms and representations. From a diachronic perspective it appears that a moment of discontinuity did take place: this can be traced back to the 1970s, when the first discursive articulations on the state's position appeared in newspaper articles presenting new values and priorities concerning funerary practice, although some of these ideas and semantic patterns had originated in the Republican period. The first intensification of the discourse occurred in 1983 with the enactment of the Grave Establishment Administration Act. From then onwards, the discourse in the press displayed a high degree of continuity and inner consistency. In its analysis of this period of apparent continuity, this chapter privileges a synchronic perspective, exploring the regularities of the discourse and the principles contributing to its inner structure. Following Foucault's understanding of discursive formations, this synchronic analysis reveals four sub-formations: first, the measurement of space in quantitative terms; second, the economy of cremation; third, the beautification of cemeteries; and fourth, arguments against geomancy, which was labeled superstitious. The discursive voices emerging from these subformations are those of state and local authorities, experts, and journalists commenting on the reform measures.

Analysis of the four sub-formations reveals that the change to funerary practice was depicted as unavoidable, particularly with reference to the limited amount of land available, making it necessary to replace the customary ground burial with cremation and either subsequent storage of the ashes in funeral urns in columbaria or natural burial. Change is 
also visible in the discourse on state authorities' priorities for funerary practice and the values that it communicated in this regard. These priorities, values, and norms displayed a secular character: the discourse made clear that state and municipal authorities prioritized space-saving measures and frugal, economic funerals, and a green landscape free of graves declared desirable values. Furthermore, a particular pattern in the discourse criticized geomancy as superstition and a contradiction in the age of science. The changed priorities for funerals show signs of the secularization of funerary practice. This chapter discusses the notion of secularization as a central term in social-scientific debate with regard to the funeral reforms.

The chapter proceeds as follows: first, the funeral reforms in Taiwan are contextualized historically in the section "Funeral Reforms in Taiwan and Their Historical Context." The section "Methodology" presents the methodology, discourse analysis, and the section "The Data: Press Articles" presents the data. The four sub-formations of the discourse are analyzed in the section "Funeral Reform in Public Discourse." The section "Secularization" discusses the notion of secularization as a metanarrative in which the funeral reforms can be located in a broader sociopolitical context, and the conclusions are presented in the section "Conclusion."

\section{Funeral Reforms in Taiwan and Their Historical Context}

Before the Nationalists began to regulate funerary practice in the context of Taiwan's land shortage and population density in the second half of the twentieth century, the Nationalist Party had already sought to regulate and reform funerary practice during the Republican period on the mainland, albeit without success. In 1928, a new law was enacted to establish public cemeteries in every county, with standardized graves and an egalitarian ideal, but it was not fully realized due to the breakout of the Sino-Japanese War in 1937. Furthermore, a project promoting cremation faced intra-party controversy and was not implemented (Fang and Goossaert 2008, 56). 
After 1949 and the GMD's retreat to Taiwan, the attempt to reform funerary practice continued: in 1983, the Grave Establishment Administration Act was enacted prohibiting the establishment of graves outside of officially registered cemeteries, which had previously been a common practice (Xu 2001, 105). A second turning point came in 2002 with a new law on funerary practice, the Mortuary Service Administration Act (Binzang guanli tiaoli 蕦葬管理佟例). A new measure included in this was the promotion of natural and sea burials. By the turn of the millennium, the cremation rate exceeded 90 per cent in large cities, and the government was eager to adopt further measures to deal with the land shortage. ${ }^{2}$ After 2002, local governments promoted sea and natural burials, with the ashes scattered at sea or buried in a biodegradable bag in designated spots under trees or in flowerbeds, so that after a few months the same spot could be reused for the next burial. A pilot tree burial project was established in 2003 in Taipei's Fude Cemetery, with further areas for tree and flower burial in other cities in subsequent years.

These reforms and new measures introduced by the government and implemented by local authorities stand in contrast to previous burial practices. Ground burial was still the most popular practice in the 1980s. ${ }^{3}$ Ethnographies demonstrate the ritual importance of ground burial and the importance of spatial arrangements in the context of burying the deceased. Ahern (1973, 175-90), for example, gives a detailed account of the extent to which geomancy (fengshui 風水) was considered relevant by the inhabitants of a village in northern Taiwan: they regarded the fengshui of a grave as an important factor that determined fortune or misfortune for the deceased's descendants. Ahern's ethnography differentiates between the villagers' knowledge and specialists' geomantic theories: professional geomancers regard fengshui as an automatic operation, meaning that if the forces and configurations around the grave are balanced, benefits will ensue automatically, while for the villagers good fengshui was about the ancestor's comfort in the grave,

\footnotetext{
2In Taipei, the capital of Taiwan, the cremation rate was reportedly as high as 95 per cent in 2002 (People's Livelihood Daily, December 29, 2002, A02).

${ }^{3}$ The Taiwanese Ministry of the Interior reported that the countrywide cremation rate was 18 per cent in 1986 (United Daily News, March 31, 1992, 6).
} 
and the ancestor him or herself was the source of subsequent fortune or misfortune.

These considerations were not included in the articulations of the state. Ritual practices and geomancy became objects of criticism due to their perceived superstitious basis and negative effects on spatial planning. Before discussing this, the methodology of this study is described.

\section{Methodology}

\section{Studying Change with Discourse Analysis}

While the laws and regulations on funerals provide insights into the state's aspiration to reform funerary practice due to the shortage of land, the state's attitude found more explicit and detailed expression in the public discourse in Taiwanese newspapers. As a methodical tool, discourse analysis reveals the rationales and justifications of the institutions involved.

The discourse, which began toward the end of the 1970s and around the time of the enactment of the Grave Establishment Administration Act in 1983, included a bundle of arguments referring to different social values and semantic patterns and aimed to promote a new ideal in funerary practice. The discourse displayed a high degree of continuity. The problem of the land shortage and the question of how to bury the deceased was discussed throughout the period under investigation until 2014. At the same time, studying the public discourse reveals changes caused by the state's intervention, as the rationales appearing in the discourse explicitly criticized and rejected certain formerly prevalent funerary practices.

\section{Discourse}

What is a discourse? Among the different notions of "discourse," Michel Foucault offers a number of concise characteristics. Although he does not provide a unified theory, different texts of his nevertheless provide 
clear indications of how discourses and discursive formations can be understood and analyzed. With regard to methodological considerations, Foucault's definition of discursive formation is particularly useful:

Whenever one can describe, between a number of statements, such a system of dispersion, whenever, between objects, types of statement, concepts, or thematic choices, one can define a regularity (an order, correlations, positions and functionings, transformations), we will say, for the sake of convenience, that we are dealing with a discursive formation [...]. (Foucault 1972, 38; emphasis in the original)

This definition puts the focus on statements as the basic elements of discursive formation. Statements are on the one hand singular units or events of interest for the discourse analyst, but on the other must be seen in relation to other statements. Statements are thus always part of a series or networks of other statements (Foucault 1972). Foucault (1971, 58-59) mentions not only regularity as a characteristic of discourses but also contingency, discontinuity, dependence, and transformation. He uses the expression "discursive events" and emphasizes that any analysis of discourse must take small events into consideration in the analysis of long-term phenomena. The emphasis here is on not only the regularity of discourse but also singular events whose contingency and discontinuity add another dimension to the analytical perspective. This means that discourse analysis has to focus on singular discursive events on the one hand, and on the regularity of the discourse on the other.

The last point concerns Foucault's idea of internal and external procedures of control: discourses are subject to procedures of control and limitation. A discourse can be internally controlled and organized, for example through systems of classification, ordering or distribution, or it can be controlled externally, for example, through prohibition, or through division and rejection as in the opposition of reason and folly, or the will to truth. An important factor here is the notion of exclusion: in any given discourse, the procedures of internal and external control are also mechanisms for excluding possible alternative voices (Foucault 1971, 10-47). 


\section{The Data: Press Articles}

The articles for analysis were found in three Chinese-language newspapers: The China Times (Zhongguo Shibao 中國時報), and United Daily News (Lianhe Bao 聯合忮) which includes United Evening News and People's Livelihood Daily (Minsheng Bao 民生報). The China Times was first published as Credit News (Zhengxin Xinwen 徵信新聞) in 1950 (Li 1977, 4), while the United Daily News, the product of a merger of three newspapers, was founded in 1951. ${ }^{4}$ People's Livelihood Daily was produced by the United Daily News group from 1978 to 2006 (Feng 2016, 237, note 2).

The sample used for this study comprises articles published between 1950 and 2014. These articles stem from two large private newspaper groups, both of which were not only pro-GMD but also had the largest circulation of newspapers in Taiwan until 1996 (Batto 2004, para. 24), and have been in continuous circulation since 1950 and 1951, respectively. ${ }^{5}$ Analysis of their articles can therefore provide a representative picture of public discourse in government-conform reporting on policymaking processes until 1988, when the control of the press was abolished. For the analysis of the press articles, it was an empirical question as to what extent the chosen newspapers also articulated the state's attitude to funeral practice after 1988 .

Under the authoritarian rule of the GMD, and until January 1, 1988, the mass media in Taiwan was controlled by the state via a range of measures containing a threefold limitation (Batto 2004, para. 5-7): a limited number of registered newspapers were permitted, with a limited number of pages, and a limited area of distribution by assigning each newspaper only one printing place.

\footnotetext{
${ }^{4}$ Following Berman (1992, 124), this merger was a reaction to difficult economic conditions for newspapers at that time.

${ }^{5}$ The founders and bosses of the United Daily News Group and The China Times, Wang Tiwu and Yu Jizhong, both of whom had previously served in the Nationalist army, became members of the GMD's Central Standing Committee between 1979 and 1988 (Batto 2004, para. 9; Feng 2016, 220).
} 


\section{Funeral Reform in Public Discourse}

What are the results of discourse analysis? According to Foucault's notion of discourse, a discourse analysis can focus on three factors: its regularity, its external mechanisms of control, and the internal principles around which it is organized.

The general regularity of the discourse was found in the argumentative structure of problematizing ritual practices. This argumentative structure enables the definition of the specificity of the discourse: in the formation of statements in which ritual funerary practices appear as a social problem. Besides the commentaries by journalists, state and local authorities were the relevant institutional discursive voices contributing to the image of funeral rituals as problematic. The chosen newspaper articles make it clear that external control of the discourse was applied through state control of the press until 1988, and, moreover, through the self-positioning of the chosen newspaper groups as pro-government.

The third aspect of the analysis, the internal principles of the discursive formation, is analyzed below. Four different sub-formations can be distinguished, each organized via different semantic patterns of criticism or problematization of funerary practices: spatial planning, with reference to Taiwan's land shortage and lack of space for graves; the economy of cremation; the beautification of cemeteries; and statements labeling certain practices superstitious.

\section{The Measurement of Space}

The first discursive sub-formation concerns spatial planning. One of the most frequent arguments for the introduction of cremation was that Taiwan, and particularly its large cities and metropolitan areas such as Taipei, is one of the world's most densely populated areas. The resulting shortage of land was leading to a situation in which there was not enough space for graves. In the newspapers sampled, this argument, which is highly consistent throughout the discourse, can be traced back to the second half of the 1970s. 
The reference to space as a finite entity that can be measured and planned significantly contributed to a view in which the funeral reforms were an unavoidable necessity. Of special relevance in this regard were arguments based on numbers and statistics: the size of graves can be quantified and compared to the area of a columbarium, allowing calculation of the surface area required for a certain number of deaths per year. In 1977, for example, The China Times cited research statistics showing that, during the past five years, there had been roughly 70,000 deaths per year, and with the size of an average grave about two pings, this meant that the annual surface area required for traditional ground burial amounted to nearly 47 hectares a year (The China Times, March 31, $1977,6) .{ }^{6}$ Due to the rapid population growth, the article predicted a situation in which "the living and the dead will compete for land," a prediction that also appeared repeatedly later in the discourse. ${ }^{7}$

\section{The Economy of Cremation}

Another discursive sub-formation consisted of the ideal of economic and frugal funerals. Officials and parliamentarians repeatedly argued against ground burial as too costly and saw cremation as an economical and frugal alternative. In 1981, a top provincial administration official, for example, suggested that promoting cremation would allow citizens to not only save money but also economize on land (sheng qian sheng di 省錢省 地, The China Times, April 4, 1981, 26). In 1983, Taipei's Department of Social Welfare was cited as stating that "In view of saving soil and money, citizens should generally adopt cremation" (The China Times, February 8, 1983, 27). Ground burial was also presented as a practice that was not only time-consuming but also inconvenient: buried mortal remains take several years to decompose, and families often had to hire a geomancer when building a grave. Cremation avoided all of

\footnotetext{
${ }^{6}$ This was probably not a realistic estimate. As a research report by the Ministry of the Interior in 1985 showed, many graves occupied a surface area of three to five or even six pings (Ministry of the Interior 1985, 30-33). A ping 坪 is a unit of area, originally introduced by the Japanese government, and equals 3.306 square meters.

${ }^{7}$ Citations from the newspapers are my own translations.
} 
these inconveniences, and ancestor worship might thus be simplified (The China Times, February 8, 1983, 27). Some years later, Taipei's Mortuary Services Office (Taibei Shi Binzang Guanli Chu 臺北市䡠葬 管理處) made a similar comparison, maintaining that cremation could save considerable effort, whereas in-ground burial required the bereaved family to purchase a coffin, hire a geomancer, and collect the bones, and conduct a second burial seven years later; all of these expenses could be saved by choosing cremation and storing the ashes in a public columbarium (United Daily News, April 18, 1991, 15). The idea that cremation would save money, time, and land is presented throughout the discourse, with similar statements found repeatedly during the 1990s and since the year $2000 .^{8}$

\section{The Beautification of Cemeteries}

The third rationale appearing in the discourse consisted of arguments against ground burial due to its effects on the aesthetics of the landscape. Since the geomantic positioning of graves involved families individually choosing a spot for each grave, tombs can be scattered over hillsides, placed close together, or positioned in a more isolated manner, contributing to what was seen as a chaotic outlook. Even in public cemeteries where the graves were placed in rows, the perception in the public discourse was often that they were not orderly. In 1999, on the occasion of Qingming, grave-sweeping day, two members of the Taipei City Council were cited in an article commenting on a Taipei public cemetery: "The graves are chaotic, and as a result tomb-sweepers cannot find their ancestors' graves" (The China Times, April 10, 1999, 18).

In the second half of the 1970s, plans were begun for cemetery and burial reforms that would eventually lead to a new design for cemeteries oriented toward a Westernized model. According to this ideal, the graves

\footnotetext{
${ }^{8}$ That people should economize on funerals was not an entirely new argument. As Hetmanczyk (2018) has shown, expensive funerary practice has been a matter for controversy in Chinese history for centuries. While a classical question was whether a luxurious funeral was a duty of filial piety, the debate received a new framing after 1912, when political economy-comprising a whole range of different economic theories-was introduced as a new order of knowledge in which funerary practice was now evaluated from an economic point of view.
} 
should be placed neatly in rows in a green and park-like environment. “Turning cemeteries into parks” (gongmu gongyuanhua 公墓公園化) was an expression repeatedly used throughout the discourse, in many instances related to the reforms. In 1976, the term appeared in a tenyear plan for the beautification of cemeteries (Taiwan Sheng gongmu gongyuanhua shi nian jihua 臺灣省公墓公圆化十年計畫) issued by the Government of Taiwan Province and its Governor, Xie Dongmin (謝東閔). A pilot scheme was established in Changhua County, and in the following years several more such projects were started in different cities and counties (for the project and its development, see $\mathrm{Xu} 2001$, 104).

An important reference point for this purpose was the Western cemetery. Taipei's Department for Social Welfare, for example, stated in 1997 that "according to the policy of 'turning cemeteries into parks', cemeteries should be designed like those in Europe and the United States, with a green lawn and the graves deep underground, with standardized gravestones aboveground" (People's Livelihood Daily, June 19, 1997, 22).

\section{Anti-Superstition}

The fourth sub-formation can be distinguished by its arguments against practices labeled superstitious (mixin 迷信). The most prominent subject of this critique was geomancy. As it was central to ground burial, with families hiring a geomancer to define a spot for the grave that should ensure an auspicious future for the deceased's descendants, many parliamentarians and public officials saw the popularity of geomancy as a major obstacle to the further promotion of cremation. In this context, it was repeatedly labeled superstitious.

In 1982, People's Livelihood Daily commented that cremation was the best solution to Taiwan's land shortage, but it was not yet sufficiently popular. The commentator saw the reason for this as the popularity of “superstitious geomancy" (mixin fengshui 迷信風水), which he contrasted with the age of science: 
Among the people believing in fengshui, many think that if the grave is well situated the descendants will be protected and guaranteed good luck; otherwise, the next generation will experience misfortune. We are now living in an age of science, but since the existence of supernatural beings and the protection granted by ancestors is difficult to prove scientifically, many people think it is better to keep believing. (People's Livelihood Daily, March 17, 1982, 6)

Geomancy was not the only practice criticized as superstitious. An article in 1991 commented on a practice at public funeral centers in Taipei where citizens chose an “auspicious day" (jiri 吉日), according to the traditional Chinese calendar, for the funeral procession to take the coffin from the funeral center to the crematorium or grave, which could be costly and elaborate. The journalist condemned the belief in auspicious and unlucky days for this as superstition, and expressed the hope that the measures introduced by the Mortuary Services Office in Taipei, reducing the fee for funerals planned on "unlucky days" and raising it on "auspicious days," would have a positive effect and might lead to the end of superstition (The China Times, September 25, 1991, 12).

How new was the use of the term mixin (superstition)? It became popular at the beginning of the twentieth century toward the end of the Qing Regime, when a new discourse emerged centering on new terms related to religious practice, among them the distinction between religion (zongjiao 宗教) and superstition (mixin). Both terms were neologisms in Chinese, imported from Japanese neologisms. Zongjiao meant religion in the Western sense of a tradition with a distinct doctrine and an organized, church-like structure, and was used to denote the realm of the acceptable, while practices marked as mixin were subject to anti-superstition campaigns (Goossaert and Palmer 2012, 50-51).

The distinct characteristic with which the notion of mixin appeared in the discourse in question was not so much the contrast with the positively connoted term "religion" as its use in labeling practices regarded as hindering the funeral reforms, particularly the introduction of cremation. The opposition between geomancy and scientifically inspired concepts for funerary practice supported the continuation of the use of 
mixin in the last quarter of the twentieth century in a new discourse in which funeral reforms in modern Taiwan took place in the context of spatial planning. ${ }^{9}$

\section{Secularization}

The emergence of a secular funerary practice vocabulary and the explicit critique of funeral rituals articulated by the state authorities suggest an analysis of the changes in funerary practice as a form of secularization.

Secularization is among the most prominent terms in the social sciences, but there is controversy about whether it should be understood as an inherent feature of modernization. Some scholars describe secularization as a consequence of modernization processes, while others, referring to the American context, emphasize religious competition as the decisive factor for the question of religious vitality. For them, the decline of religious practice in some European countries was less a result of modernization than of state regulation and church dominance. European countries, in their view, lack religious competition (see Gorski 2003 for this debate).

For an analytical perspective on the situation in Taiwan, it is helpful to distinguish between different connotations of the notion of secularization. Following Casanova (2006), the term secularization can denote the decline of religious beliefs, the privatization of religion, or the differentiation of non-religious societal spheres and their emancipation from religion. This analytical distinction is important in the context of religion in Taiwan and its evolution in times of economic development and democratization, processes generally associated with modernization. Authors such as Clart (1995/1996) and Katz (2003) have found that religious practice did not decline after 1949, and greater economic development and more wealth meant that even more temples were established and older temples were replaced by grander ones (Jordan 1994, 142). A

\footnotetext{
${ }^{9}$ Concerning the terminology, two aspects stand in continuity with the early twentieth century: the subsumption of geomancy as superstition on the one hand and the opposition between superstition and science on the other. Both terminological pairs were already present in the early twentieth century, as Goossaert and Palmer (2012, 50-53) have shown.
} 
look at the statistics on registered Buddhist and Daoist temples reveals continuous growth in their number throughout the twentieth century, from 3661 in 1930 to 5531 in 1981 and 9707 in 2001 (Katz 2003, 396) and 11,999 at the end 2017 (Ministry of the Interior, n.d.). Although it can be difficult to determine the exact use of designations such as "Buddhist" and "Daoist" in the Taiwanese context, there has nevertheless been continuous growth in the number of temples over the past 90 years.

A detailed analysis of secularization of Taiwan's religious field cannot be included here, but the growth in the number of registered temples indicates that the term "secularization" cannot be applied without reservation, as temples are places of public ritual and religious practice. How then can the notion of secularization be useful in the given case? Casanova's (2006) third aspect of secularization, the differentiation of societal spheres, is of primary interest here. Besides Casanova, other authors also mention societal differentiation as a core element of secularization (see for example Bruce 2002, 8; Luhmann 2002, 278-319).

Differentiation became evident in the discourse analysis: the rationales and solutions brought forward in the public discourse showed that the state was seeking to reform funerary practice using arguments from outside the religious field. The rationales at stake did not refer to religious content, nor did they particularly involve religious rituals. On the contrary, the view of religious and ritual practices as problematic was brought forward in various ways as a reason for planning and implementing reforms pursuing secular objectives.

A further aspect of the secular aspect of Taiwan's funeral reforms was their similarity to funeral regulations in other regions of the world. In some Asian regions, for example, funeral reforms were similarly implemented in response to land shortages. In Hong Kong, cremation had been encouraged by the colonial government since the 1960s and had been increasingly accepted, with the cremation rate rising from 35 per cent in 1976 to 68 per cent in 1993 (Teather 1999, 410). In Singapore, in the 1950s and 1960s, a state discourse on land use conflicted with Chinese geomancy, as the state regarded burial grounds as an impediment to the economical use of land and the development of the nation state (Yeoh and Tan 1995). In Japan, cremation has been promoted since the Meiji period: although the Meiji government declared a ban 
on cremation in 1873, voices arose in favor of it, and the ban was lifted only two years later (Bernstein 2000, 298). Scattering the ashes after cremation emerged as a new practice in the 1990s (Kawano 2004).

In regions such as Hong Kong, Singapore, and Japan, where ground burial practices have been challenged and/or cremation was promoted, the discursive frames were all influenced by a Western or Westernized perspective as a result of the presence of colonial powers, as in Hong Kong and Singapore, or an attitude orientated toward Western practices, as in the case of Japan. During the Meiji era, pro-cremation voices in the 1870s were already oriented toward Europe and the United States at a time when the first cremation societies were being formed there (Bernstein 2000, 320-22). Cremation as a modern project in Asian regions was then to a large degree a project of Westernization. This was also the case in Japan, where cremation, already known as a Buddhist practice, was promoted by the Meiji bureaucrats based on secular rationales such as hygiene (Bernstein 2000).

This means that Taiwan followed the global spread of cremation as a modern project as found in other regions in the West and Asia. The Taiwanese institutions' discourse on funeral reforms and the policymaking process were explicitly inspired by and orientated toward those of other countries. In a Taipei City Council discussion in 1995, for example, the commissioner of the Department of Social Welfare, to which the Mortuary Services Office belonged, demanded that the City government should follow the examples of Singapore, Hong Kong, and Japan and introduce a regulation setting a temporal limitation for the use of grave plots in public cemeteries (People's Livelihood Daily, August $4,1995,22)$. In other instances, the authorities involved traveled abroad to study other countries' funeral regulations. In 2001 an official of the Department of Civil Administration of Taiwan's Ministry of the Interior was cited expressing admiration for various methods of natural burial in a newspaper article reporting on his visit to Australia and New Zealand (People's Livelihood Daily, January 10, 2001, 4).

The emergence of a new state rhetoric with secular rationale on funerals was therefore part of a global pattern. Secularization, in the sense of the emerging presence of a secular state, is not a local invention of 
Taiwanese institutions but part of a larger, transnational process and the diffusion of ideas on funeral reform derived from Western ideals. The secularization of Taiwan's funeral reforms is thus to a large degree the result of Westernization. ${ }^{10}$

\section{Conclusion}

This chapter has analyzed a discourse in the written media in which state rhetoric on funerals appeared from the late 1970s onwards. Discourse analysis was presented and applied as a method for examining social change and continuity by revealing ideals and values the authorities introduced into the field of funerary practice, and analyzing the rationales by which they argued for change and funeral reforms. On the one hand, the justifications for and rationale behind the reforms appeared with a high degree of continuity and consistency in the decades after the 1970s, while on the other their appearance also marked a discontinuity and a break from the religious rituals prevalent at funerals, as the state's rhetoric was based on secular justifications for the reforms and was critical of the use of ritual. Following the writings of Foucault, it has been possible to discern four different discursive sub-formations, the analysis of which has led to conclusions about the discontinuity in the field of funerary practice in Taiwan, locating this social change within the broader sociopolitical context.

A salient feature of the discursive articulations is the presentation of the reforms as unavoidable, in particular with reference to the limited space available for cemeteries. Arguments based on numbers in this context contributed to the objectivity with which the necessity for the reforms was presented. The discourse reveals in detail how secularization took place in the context of funeral reforms. The state's priorities for

\footnotetext{
${ }^{10}$ In Western regions, on the other hand, comparable secularization tendencies can be observed in mourning and funeral practices. As Lüddeckens (2018) has shown, for example, death rituals in Switzerland are becoming increasingly detached from the institutionalized (church) context. Instead, independent celebrants offer rituals designed using symbology that is open to interpretation by those of different religious and non-religious persuasions. The Swiss independent celebrants invoke a kind of natural religion: "Nature is communicated as the entity that encompasses the living and the dead, life and death" (Lüddeckens 2018, 117).
} 
these reforms were dominated by a rationalized perspective on the space available and on funeral behavior that did not include elaborate rituals or the use of geomancy for siting graves. This perspective found expression in claims that space-saving practices such as cremation or natural burial were necessary, and adhered to science as a desirable standard, criticizing geomancy as superstitious and incompatible with the scientific age. Part of this communication of new values for funerals was an orientation toward Westernized ideals, particularly green, park-like cemeteries modeled on those in the West, and natural burial inspired by Australian practice. The secularization realized in the funeral reforms can be contextualized within broader transnational developments. The regulation of funerary practice in the context of spatial planning, the introduction of cremation, and the resulting changes in ritual practice occurred in similar ways in different regions around the globe, and Taiwan's state authorities sought inspiration for its funeral reforms from developments in other countries. Analysis of this discourse has thus allowed the contextualization of Taiwan's reform measures and attempts to induce changes to its funerary practices in a broader, global context.

\section{Bibliography}

\section{Primary Sources}

People’s Livelihood Daily (Minsheng Bao 民生報), daily newspaper in Chinese. The China Times (Zhongguo Shibao 中國時報), daily newspaper in Chinese. United Daily News (Lianhe Bao 聯合報), daily newspaper in Chinese.

\section{Secondary Sources}

Ahern, Emily. 1973. The Cult of the Dead in a Chinese Village. Stanford: Stanford University Press.

Batto, Patricia R. S. 2004. "The Consequences of Democratisation on Taiwan's Daily Press." China Perspectives 51. http://journals.openedition.org/chinap erspectives/791. Accessed April 4, 2019. 
Berman, Daniel K. 1992. Words Like Colored Glass: The Role of the Press in Taiwan's Democratization Process. Boulder, CO et al.: Westview Press.

Bernstein, Andrew. 2000. "Fire and Earth: The Forging of Modern Cremation in Meiji Japan.” Japanese Journal of Religious Studies 27 (3/4): 297-334.

Bruce, Steve. 2002. God Is Dead: Secularization in the West. Malden: Blackwell.

Casanova, José. 2006. "Rethinking Secularization: A Global Comparative Perspective." The Hedgehog Review 8: 7-22.

Clart, Philip. 1995/1996. "Sects, Cults, and Popular Religion: Aspects of Religious Change in Post-War Taiwan." British Columbia Asian Review 9: 120-63.

Fang, Ling and Vincent Goossaert. 2008. "Les réformes funéraires et la politique religieuse de l'État chinois, 1900-2008." Archives de Sciences Sociales des Religions 144: 51-73.

Feng, Chien-san. 2016. "Press Freedom and the Mass Media." In Taiwan's Democracy Challenged: The Chen Shui-bian Years, edited by Yun-han Chu, Larry Diamond, and Kharis Templeman, 219-39. Boulder, Co/London: Lynne Rienner.

Foucault, Michel. 1971. L'ordre du discours: Leçon inaugurale au Collège de France prononcée le 2 décembre 1970. Paris: Gallimard.

Foucault, Michel. 1972. The Archaeology of Knowledge. New York: Pantheon.

Goossaert, Vincent, and David A. Palmer. 2012. The Religious Question in Modern China. Chicago: University of Chicago Press.

Gorski, Philip S. 2003. "Historicizing the Secularization Debate. An Agenda for Research." In Handbook of the Sociology of Religion, edited by Michele Dillon, 110-22. Cambridge et al.: Cambridge University Press.

Hetmanczyk, Philipp. 2018. Reichtum begraben: Kostspielige Bestattungspraxis in China zwischen Religionspolitik und Religionökonomie. Berlin: De Gruyter.

Jordan, David K. 1994. "Changes in Postwar Taiwan and Their Impact on the Popular Practice of Religion." In Cultural Change in Postwar Taiwan, edited by Stevan Harrell, and Chün-chieh Huang, 137-60. Boulder, CO et al.: Westview Press.

Katz, Paul. 2003. "Religion and the State in Post-war Taiwan." The China Quarterly 174: 395-412.

Kawano, Satsuki. 2004. "Scattering Ashes of the Family Dead: Memorial Activity among the Bereaved in Contemporary Japan." Ethnology 43 (3): 233-48.

Li, Tze-chung. 1977. "Publishing in the Republic of China." Journal of Library and Information Science 3 (2): 1-16. 
Lüddeckens, Dorothea. 2018. "Alternative Death Rituals in Switzerland: Building a Community of Shared Emotions and Practices." Journal of Contemporary Religion 33 (1): 107-21.

Luhmann, Niklas. 2002. Die Religion der Gesellschaft. Frankfurt am Main: Suhrkamp.

Ministry of the Interior. 1985. Taiwan beibu quyu sangzang wenti diaocha baogao 臺灣北部區域喪葬問題調查報告. Taipei: Ministry of the Interior. Ministry of the Interior. N.d. Statistical Yearbook. https://www.moi.gov.tw/files/ site_stuff/321/2/year/year_en.html. Accessed April 4, 2019.

Teather, Elizabeth K. 1999. "High-Rise Homes for the Ancestors: Cremation in Hong Kong.” Geographical Review 89 (3): 409-30.

Xu Fuquan 徐福全. 2001. “Taiwan binzang lisu de guoqu, xianzai yu weilai 臺 灣䫂葬禮俗的過去, 現在與未來”. Shequ fazhan qikan 社區發展季刊 96: 99-108.

Yeoh, Brenda S. A., and Boon Hui Tan. 1995. "The Politics of Space: Changing Discourses on Chinese Burial Grounds in Post-war Singapore." Journal of Historical Geography 21 (2): 184-201.

Open Access This chapter is licensed under the terms of the Creative Commons Attribution 4.0 International License (http://creativecommons.org/ licenses/by/4.0/), which permits use, sharing, adaptation, distribution and reproduction in any medium or format, as long as you give appropriate credit to the original author(s) and the source, provide a link to the Creative Commons license and indicate if changes were made.

The images or other third party material in this chapter are included in the chapter's Creative Commons license, unless indicated otherwise in a credit line to the material. If material is not included in the chapter's Creative Commons license and your intended use is not permitted by statutory regulation or exceeds the permitted use, you will need to obtain permission directly from the copyright holder. 